\title{
Paths, Events and Resource Use: New Developments in Understanding Innovation
}

\section{Processes}

\begin{abstract}
The purpose of this paper is to investigate innovation paths, their events and resource use for a wave energy development company within the renewable energy sector. An in-depth single case study mixed-method methodology was used to examine a detailed typology of events and develop innovation paths where one category of resources is predominant (technical or commercialization), or where the resources are evenly combined (ambidextrous). The case study results highlight the early presence of a new innovation path type (ambidextrous), offer a better understanding of the different resources used along each path type, and show that cooccurrence of events (common events) across paths influences path convergence. As a practical implication, the paper underlines the benefits of ambidexterity and the multifaceted role of government within the business network, requiring the focal organization to reconsider its interactions with various government departments and other agencies.
\end{abstract}

Keywords: Innovation path; technical, commercialization, and ambidextrous paths; events; lock-in effects; resource use; renewable energy 


\section{Introduction}

Innovation occurs when actors re-configure network resources to develop novelty and creativity (Lichtenstein \& Brush, 2001). Small innovative organizations and entrepreneurs often lack the ability to access internally all resources required, rather relying on their business network to be able to mobilize required resources (particularly knowledge) (Ostendorf, Mouzas, \& Chakrabarti, 2014; Rusanen, Halinen-Kaila, \& Jaakkola, 2014; Ståhl \& Waluszewski, 2007; Villanueva, Van de Ven, \& Sapienza, 2012). Moreover, it is not just which resources are accessed from the network, but also how resources are deployed within innovation processes (Purchase, Olaru \& Denize, 2014b). In particular, there are contradictory results on the success of ambidextrous innovation strategies (Simsek, Heavey, Veiga \& Souder, 2009; Ambos, Mäkelä, Birkinshaw \& D'Este, 2008). Ambidextrous innovation strategies use resources to develop both exploratory and exploitative knowledge, even though very different skills and capabilities are required. This research investigates how different categories of resources exchanged during innovation events influence innovation development. In particular, it investigates how resource use during innovation processes via different common events, influences innovation paths.

This research incorporates the notion of multiple innovation paths occurring sequentially and/or in parallel over time (Makkonen, Aarikka-Stenroos \& Olkkonen, 2012; Araujo \& Harrison, 2002). An innovation path is a sequence of innovation events that are time dependent (Makkonen et al., 2012). Thrane, Blaabjerg and Møller (2010) previously highlighted two types of paths: technical and commercialization. This research signals the critical role of another type: ambidextrous path. Compared to the first two types, an ambidextrous path has additional benefits because it uses knowledge, financial, and social capital in approximately similar amounts, thus enhancing flexibility. We use the term ambidextrous as the organization is using multiple resources together, rather than using a single resource type that dominates the path.

Investigating innovation through event analysis allows the research to incorporate dynamics and longitudinal perspectives (Chou \& Zolkewski, 2012), which represents a current gap in the innovation literature (Dagnino, Levanti, Minà, \& Picone, 2015). Van de Ven, Polley, Garud, and Venkataraman (2008, p. ix) indicate that 'an appreciation of the temporal sequence of events is [...] fundamental to managing innovation'. Building on previous innovation event analysis research (e.g. Van de Ven et al. 2008), this research links events, to 
build innovation paths. Previous research on innovation paths (e.g. Thrane et al., 2010; Simmie, Sternberg, \& Carpenter 2014; Garud, Gehmanb, \& Giuliani, 2014) has not necessarily adopted an event analysis perspective, although Makkonen et al. (2012, p. 294) argues that it helps in analyzing the 'plot type' (e.g. innovation paths).

Given the gaps highlighted above, three research questions encapsulate our research aim:

1. What types of innovation events and paths are shaping the development of the wave energy innovation?;

2. How does resource use influence the types of innovation paths?;

3. How do common events within multiple paths influence future paths?

A mixed methodology investigation is adopted to analyze data from the renewable energy sector, using a case study of the development of a wave energy device in Australia. Content analysis of reports and interviews is followed by quantitative analysis of events and resources, providing complementing evidence to support the qualitative examination.

This investigation makes a number of contributions:

- depending on the innovation paths, resources are reconfigured and recombined continuously, with common patterns identified for three innovation path types: predominantly technical or commercialization, and ambidextrous;

- ambidextrous innovation paths require 'balanced'/joint use of all resources, rather than one resource category dominating;

- common critical events across paths reinforce future path convergence.

The remainder of this article is structured as follows: Section 2 presents the literature review in resource use, innovation events and time, along with a description of the innovation paths. These concepts are then linked together to highlight how they contribute to innovation processes. Section 3 details the methodology adopted for the study and describes the case study. Following the results (Section 4), the final section presents the findings and implications for theory and practice, as well as ideas for furthering the research.

\section{Literature Review}

\subsection{Resources Deployed within Innovation Processes}

Resource 'bundles' rather than a single resource category are important within innovation processes (Lichtenstein \& Brush, 2001; Purchase, Olaru \& Denize, 2014a). For example, financial capital can be used to acquire knowledge resource and develop social capital and 
vice versa (Rusanen et al., 2014). Exploitative knowledge and social capital successfully deployed lead to the accumulation of financial capital in terms of sales (Ostendorf et al., 2014). Previous research found the following three broad resource categories were particularly important within innovation resource bundles: financial capital, social capital and knowledge (Gupta \& Govindarajan, 1991; Lichtenstein \& Brush, 2001) and are the focus of our research.

Soft intangible resources or social capital have been previously associated with improved knowledge acquisition and integration, leading to improvement in innovative capabilities (Pérez-Luño, Cabello Medina, Carmona Lavado \& Cuevas Rodríguez, 2011). Social capital is described here as 'the sum of resources that a firm can access or mobilize by virtue of possessing a durable network of relationships' (Yli-Renko, Autio, \& Tontti, 2002, p. 282). The ability to finance innovation development is important in shaping the innovation trajectory (Dosi, 1982) and allows for a greater amount of experimentation, which leads to improved novelty and consequently higher long-term innovation performance (Partanen, Möller, Westerlund, Rajala \& Rajala, 2008). Therefore, both social capital and financial capital are included in this investigation.

Knowledge is an important input and output of innovation relationships (Baraldi \& Waluszewski, 2007). Different types of knowledge have been identified. Rusanen et al. (2014) differentiated between tacit knowledge, organizational routines, confidential information and general information. Waluszewski and Håkansson (2007) categorized knowledge into specialist and general knowledge use, while others consider exploratory and exploitative knowledge (e.g. Land, Engelen \& Brettel, 2012; Purchase et al., 2014a; Van de Ven et al., 2008; Lin, McDonnough, Lin, \& Lin, 2013; Simsek et al., 2009). Exploratory knowledge is described as knowledge aligned with the technological experimentation, while exploitative knowledge is knowledge aligned with technological extension and refinement (Land et al., 2012). There are numerous motivations to mobilize knowledge, including economic, technical and strategic (Waluszewski \& Håkansson, 2007). The use of knowledge within actor interactions is also constantly evolving. Innovation paths constrain what types of knowledge develop, while alleviating uncertainty (Ståhl \& Waluszewski, 2007). Moreover, the heterogeneity of knowledge resources developed influence innovation paths via decisions and processes (Ståhl \& Waluszewski, 2007). 
Ambidexterity is 'an organization's ability to perform differing and often competing strategic acts at the same time' (Simsek et al. 2009, p. 865). In relation to innovation processes ambidexterity is often aligned with the use of exploration and exploitation innovation processes occuring simultaneously or sequentially (e.g. Simsek et al. 2009; Lin et al., 2013, Sullivan \& Marvel, 2011). Given that these two processes have differing requirements on resource use, particularly knowledge, organizations need to make trade-offs in allocating resources and prioritize decision-making (Lin et al., 2013). Previous research on the outcomes of ambidexterity is inconclusive, with some results indicating improved innovation performance (e.g. Lin et al., 2013; Raisch \& Birkinshaw, 2008), while others suggest nonsignificant improvements (e.g. Sullivan \& Marvel, 2011).

\subsection{Innovation Events}

Events are defined as 'temporally specific outcomes of performed acts by actors' (Hedaa \& Törnoos, 2008, p. 324) that require resources (Chou \& Zolkiewski, 2012). Events are interdependent as they are performed in anticipation of a future event or a response to a previous event (Håkansson \& Snehota, 1995). Events have also been described as critical junctures (Vohora, Wright, \& Lockett, 2004), episodes (Ostendorf et al., 2014) or activities (Makkonen et al., 2012). Events vary according to the innovative context (Chou \& Zolkiewski, 2012) and criteria includes: activity type (Van de Ven et al., 2008; Ostendorf et al., 2014; Vohora et al., 2004), importance to the process under investigation (Halinen, Törnroos, \& Elo, 2013; Chou \& Zolkiewski, 2012), and alignment to focal innovation processes or context (Makkonen et al., 2012).

Makkonen et al. (2012, p. 293) highlights that network processes are 'overloaded with relevant and irrelevant actions, events and actors'. Previous research focuses on the most important events, though this approach risks overlooking critical network processes (Halinen et al., 2013). Thus, critical, related and background events all need to be included within the analysis (Halinen et al., 2013). Critical events are key actions/activities that drive the progression of the innovation or are points of departure from current process directions (Tidström \& Hagberg-Andersson, 2012). Related events are actions or activities that directly trigger or result from critical events, but do not carry significance to the innovation process by themselves. Background events relate to the context in which the innovation is embedded, such as macro-environmental context and institutional forces. 
This research also includes lock-in events, described as events that constrain future events (Arthur, 2009). Although the focus here is on events, many different types of components in the innovation process have been shown to display lock-in effect. Examples include: technological paradigms (Dosi, 1982), institutional constraints (Arthur, 2009; Simmie et al., 2014), historical accidents (Simmie et al., 2014), introducing complementary technologies (Dosi, 1982; Araujo \& Harrison, 2002), changing network structure in which the innovation is embedded (Waluszewski \& Håkansson, 2007), changing knowledge structure of the innovation network (Araujo \& Harrison 2002; Waluszewski \& Håkansson, 2007), and uncertainty of future innovations (Jenkins \& Floyd, 2001).

\subsection{Innovation Paths}

Paths are sequences of events where future events are serially dependent on the patterns of past events (Araujo \& Harrison, 2002) or 'particular sequence of events unfolding' (Garud \& Karnøe, 2013, p. 33). Given the interdependencies between events, paths allow researchers to investigate event dependence, though analysis does have the advantage of hindsight given it is undertaken post the events (Makkonen et al., 2012). Innovation path categories include: a) technical paths that outline technical events; and b) commercialization paths that relate to ' $a$ specific strategy, business model, or organizational approach to innovation' (Thrane et al. 2010 , p. 941). Thus, the resources used within each path category may vary according to the event type included.

Innovation consists of multiple innovation paths developing along parallel and/or sequential sequences (Araujo \& Harrison, 2002). Thrane et al. (2010) described parallel paths where technical and commercialization paths occur together within the same chronological time periods. Makkonen et al. (2012) described sequential paths by pooling relevant stories and then analysing them via a plot type. But, how do these paths interact with each other? There is a limited understanding of notions such as: convergence/divergence (Dosi, 1982; Öberg \& Shih, 2014); reinforcement/reactive (Araujo \& Harrison, 2002) and the combination and timing of events within the paths (Woodside \& Biemans, 2005). Convergence can be considered from technological paradigms (Dosi, 1982); convergent logic (Öberg \& Shih, 2014) while re-using existing knowledge leads to convergent paths (Araujo \& Harrison, 2002). Woodside and Biemans (2005) highlighted that reinforcing paths can lead to both successful and unsuccessful innovation. 


\section{Data and Case Story}

\subsection{Case Description}

The company develops wave energy devices ${ }^{1}$ for electrical power generation. It emerged from a diversified private organization, originally involved in mining exploration. In 1999, the company started to investigate technology projects to expand its activities and asset base. The first technology acquired was a marine technology invented by the Chairman of the company's board. Following the successful sale of the marine technology in 2001, the company acquired several others technologies invented by the Chairman, one of which is a wave energy device. It was not until 2009 that the company chose to focus solely on developing and commercializing the wave energy technology.

The development of the wave energy device, acquired in 2001, occurred firstly as part of a consortium formed with a large Australian-based renewable energy company (2003) and subsequently, in a joint venture (2004), when a separate company was listed in the London Stock Exchange (AIM). The aim of this decision was to commercialize the wave energy device. Under the joint venture arrangement, the company provided technical expertise required for the development of the wave energy device but did not have ownership of the technology, resulting in problems within the fundraising processes. To overcome this problem, the company negotiated the operating license for wave energy projects in the Southern Hemisphere. With this license, the company had its first successful ASX capital raising. It also kick-started the company's first attempts to seek out commercial opportunities for technology demonstration. The securing of the operating license coincided with the appointment of a new CEO, who also introduced a more formal structure into the company and assembled a skills-appropriate team for technological development. In 2009, the company fully acquired the IP and global rights for the wave energy device, an important strategic move.

\footnotetext{
${ }^{1}$ Wave energy refers to the power source from the endless move of waves generated from four sources: bodies moving on or near surface; winds; seismic disturbances; lunar and solar gravitational fields (McCormick, 2013). Wave energy is widely available and easily predictable (compared to wind) and environmentally friendly (green). Its potential is substantial and the amount of energy is proportional with the square of the wave height (McCormick, 2013). However, it may create hazards for marine life near the equipment and its performance is currently limited, thus the extraction costs are high. Although not new, the wave energy has only recently been harnessed (Fadaeenejad et al., 2014).

Numerous types of devices are available (Babarit et al., 2012). In the case study the company applies bottomreferenced submerged heave-buoys. These buoys are connected to the sea-bed and under wave action, their moves trigger wire pulls that drive a linear generator.
} 
The effort to seek out commercialization opportunities began back in 2004, mainly through formation of partnership with a local entity, or establishment of a subsidiary. The UK-listed company established several relationships in France, Canada, and Bermuda, which they deepened in 2010. However, these opportunities have failed to advance since that time, due to a lack of funding and government support. In Australia, the company was successful in obtaining government funding and approvals for a demonstration project in 2012. The company also explored several overseas markets, including Ireland, Chile and UK. In 2014 a project location in UK was secured for the demonstration of version 6 of its technology. The projects in Ireland and Chile remain in the pipeline.

Demonstration projects always begin with a feasibility study of the natural environment, thus, requiring unique designs for each location. This process requires the company to work with many different stakeholders, such as: suppliers for the various parts needed for the wave energy device, government entities for the approval of site, local communities when consultations are conducted, contractors for equipment installation required for conducting geographical and environment surveys, a local electricity supplier for connection of the devices to the grid. Although initially experiencing difficulties in finding suitable suppliers, the company now has an established network of reliable contractors and suppliers with which to work.

The company relies on three main sources of funding: the stock market, private equity and government grants. Since 2009, the company has successfully raised capital through selling of shares on the stock market, private equity investment, and government awards. The decision to be listed on the stock market was made in response to the shallow pool of private equity available in Australia at the time, and the increased risk adversity among private investors after the Global Financial Crisis. Between the three funding options, the company has had a preference for government grants because: they provide a 'non-diluting' form of funding, decisions on locations and commencement of demonstration projects are in the hands of government, and government endorsement can help boost investors' confidence in the company (source: Managing Director (MD) and Board Member). As such, successful government grants strongly influenced the company's commercialization strategy. As an example, the first demonstration project in Western Australia was enabled by several local and federal government grants. Similarly, the failure to secure government funding in France 
and Canada, has resulted in projects being stalled (Please refer to the Company Timeline in Appendix 1).

Besides being the source of funding for the company, government also has an influential role as a customer and, possibly, a competitor. As site owners, government provides permission and licenses for project locations. The company needs to acquire these approvals and licenses from various government bodies before a project becomes feasible. So, the company maintains close relationships with various governments (state and federal) by hosting visits at the company's facility, participating in industry bodies, engaging in exchanges (e.g. presentations and seminars), and hiring people with good connections within government bodies. As the main controller of the electricity infrastructure and power generation entities, governments are also potential competitors to the company. The attitude of the government towards sustainable technologies, especially wave energy, greatly affects the company's market focus. As an example, in response to the favorable attitudes of the UK and Irish governments towards wave energy, the company set up both a UK and Irish branch, and concentrated their marketing effort in these regions.

The event analysis tells the story of the company from 1975 to 2014. Since then, as of 2015, the company had successfully completed the demonstration project in Western Australia and is currently testing the next version of the technology, as well as exploring opportunities in the UK and remote islands. The full acquisition of the IP and global rights to the wave energy device is a significant point in the company's history as it repositioned the company's focus onto wave energy development. Therefore, processes occurring a priori and a posteriori of the decision to focus on the current wave energy technology were analyzed separately, in two life stages of the organization. Given the number and diversity of processes occurring within each life stage, innovation paths were developed independently.

\subsection{Data}

Data consisted of face-to-face interviews and publically available secondary data such as newspaper and magazine articles, blogging sites, websites and Australian Stock Exchange (ASX) announcements. The organization emerged from a mining company, which diversified its activities into technology development and repositioned its focus solely on sustainable technologies in 2006. The company listed on the ASX in 1993 and as such is under the reporting standards of ASX to release announcements whenever a major change occurs. 
Consequently, $90 \%$ of the secondary data came from ASX and media articles, similar to Bairstow and Young (2012). This added up to a total of 297 announcements and annual reports spanning the period 1995 to 2014, and 286 media reports from 2001 to 2014. Four semi-structured interviews were also conducted, with each interview taking between 50 to 70 minutes. Table 1 provides details of the interviewees, their current position and a brief description of their involvement. All interviews were fully transcribed and sent back to interviewees for comments. A total of 67 pages of single-spaced transcribed text were available for analysis.

Table 1 Interviewee Details

\begin{tabular}{|l|l|l|}
\hline & Current Position & Involvement \\
\hline $\begin{array}{l}\text { Interview A } \\
(2007-\text { present })\end{array}$ & $\begin{array}{l}\text { Chief Operating Officer } \\
\text { (COO) }\end{array}$ & $\begin{array}{l}\text { Originally employed as a Business Development } \\
\text { Manager and since promoted to COO }\end{array}$ \\
\hline $\begin{array}{l}\text { Interview B } \\
(2005-\text { present })\end{array}$ & $\begin{array}{l}\text { Managing Director (MD) and } \\
\text { Board Member }\end{array}$ & $\begin{array}{l}\text { Originally employed as Manager of Innovation and } \\
\text { Technology and since promoted to MD }\end{array}$ \\
\hline $\begin{array}{l}\text { Interview C } \\
\text { Intermittently } \\
1995-\text { present })\end{array}$ & $\begin{array}{l}\text { Private Investor and Board } \\
\text { Member }\end{array}$ & $\begin{array}{l}\text { Originally managing investment through a venture } \\
\text { capital fund in 1995; then through an energy } \\
\text { company 2002 - 2004, followed by a private } \\
\text { investor; lastly, board member due to gained } \\
\text { industry experience }\end{array}$ \\
\hline $\begin{array}{l}\text { Interview D } \\
\text { intermittently } \\
2002-\text { present) }\end{array}$ & Board Member & $\begin{array}{l}\text { Originally managing investment of an energy } \\
\text { company 2002 - 2004; board member due to } \\
\text { experience in the industry }\end{array}$ \\
\hline
\end{tabular}

Interviewees were asked to give their story around the journey of the innovation, relationships developed, resources required and the strategic and business model changes undertaken during the time period. All interviews began with a broad open-ended question to encourage interviewees to share aspects of their experience with the wave energy technology within the company, followed up by more specific questions on timing and resources. Probing questions were asked to obtain clarifications and additional information on critical decisions, relationships, problems encountered, and utilization of resources. Closed-ended questions were also used when explanations were required regarding information obtained from secondary sources (e.g., ASX announcements, media reports).

\section{Analysis and Results}

To capture the dynamics and multi-dimensional issues involved in innovation process research, this paper used a longitudinal case study approach (Halinen \& Törnroos, 2005; 
Makkonen et al., 2012). A focus on dynamics and multi-level innovation research is lacking within B2B studies (Dagnino et al., 2015) with case studies using a narrative event methodology (Makkonen et al., 2012). Given that resource use is unique for each innovation (Lichtenstein \& Brush, 2001), a case study approach can capture these unique events, allowing researchers to incorporate the complexity of the context under investigation (Halinen \& Törnroos, 2005). A longitudinal case study enables the investigation of innovation evolution (Codini, 2015) through focusing on events (Makkonen et al., 2012; Halinen et al., 2013).

\subsection{Methodology}

A mixed methods research (MMR) approach was applied for analysing data (Cresswell \& Plano Clark, 2011). MMR refers to collecting, analysing and interpreting both qualitative and quantitative data in a single study that explores the same underlying phenomena (Leech \& Onwuegbuzie, 2009; Wolf, 2010). Our MMR approach uses multiple qualitative methods and one quantitative. Firstly, to investigate actor perceptions we analysed the interview transcripts and documentary data using Leximancer. These results, which highlight actor perceptions on innovation processes (Section 4.2) assisted with the event coding, showing which events were perceived as being more important than others. Secondly, innovation paths were developed using event analysis (Section 4.3), similar to Makkonen et al. (2012) and Halinen et al. (2013). To assess resource use across different innovation path types non-parametric $\chi^{2}$ tests were conducted, comparing resources coded across each path category.

\subsection{Leximancer Analysis \& Results}

Interviews and documentary data (in particular the ASX announcements) were analyzed to construct a semantic map of multiple actor perceptions of how the innovation developed. Leximancer has been used as a qualitative data analysis tools on a number of projects (e.g. Munksgaard \& Medlin, 2014; Purchase, Da Silva Rosa, \& Schepis, 2015) and uses a learning algorithm to develop clusters of related concepts, which are grouped into themes to display a semantic map (Smith \& Humphreys, 2006; Leximancer Manual, 2011). This approach reduces coder bias, hence improving reliability (Penn-Edwards 2010). However, the researcher controls a number of parameters (e.g., number of themes and concepts) that are included in the analysis, based on the research questions and richness of available information. In this research an iterative process was conducted and concepts that did not relate to the research focus or were not meaningful (e.g. "possibly") were removed from the 
analysis before focusing on the final semantic map (Figure 1). This map was then checked for stability, with several runs being compared to assess if the conceptual map remains the same. The results shown in Table 2 were produced seven times out of 10 repeated runs. The alternative model that emerged for the rest of the repeated runs displayed the same first five dominating themes (but with distinct theme connectedness) with a different combination of weaker themes, with connectedness value $<10 \%$. Thus, the five main themes are consistent across multiple runs.

Figure 1: Leximancer Semantic Map

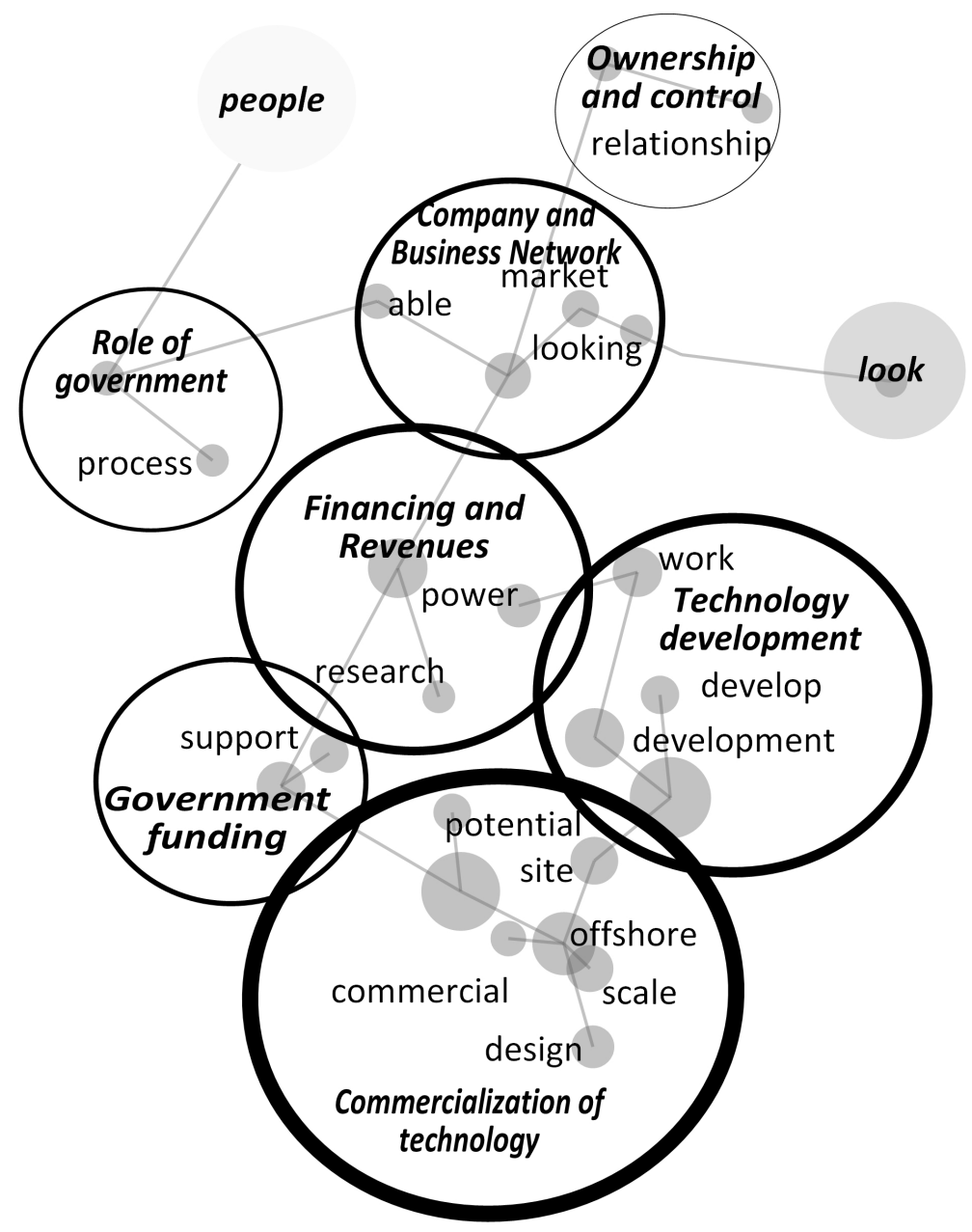

The results in Figure 1 and Table 2 assist us in understanding emerging aspects that explain innovation outcomes and changes occurring over time. Although the map is objectively derived from the semantic content, its interpretation remains a prerogative of the researcher. Figure 1 displays the semantic map output from the Leximancer analysis, edited in Inkscape. More important concepts (e.g. project) have much larger nodes than minor concepts (e.g. 
potential). The strongly connected themes are indicated with bold, thick contours, and the weaker themes using finer/thinner borders. Table 2 provides the theme connectedness and the concepts and descriptions for those themes.

Table 2 Leximancer Theme Results

\begin{tabular}{|c|c|c|}
\hline $\begin{array}{l}\text { Theme } \\
\text { (connectedness) }\end{array}$ & Concepts & Descriptions \\
\hline $\begin{array}{l}\text { Commercialization of } \\
\text { technology }(100 \%)\end{array}$ & $\begin{array}{l}\text { Project, } \\
\text { commercial, site, } \\
\text { scale, design }\end{array}$ & $\begin{array}{l}\text { - Commercialization of other technologies (with } \\
\text { potential) } \\
\text { - Commercial deployment of wave energy } \\
\text { device through projects at various sites } \\
\text { - Commercial activities at various mineral sands } \\
\text { sites } \\
\text { Technical development of the various } \\
\text { technologies as part of commercialization }\end{array}$ \\
\hline $\begin{array}{l}\text { Technology } \\
\text { development (73\%) }\end{array}$ & $\begin{array}{l}\text { Technology, } \\
\text { development, } \\
\text { work, develop }\end{array}$ & $\begin{array}{l}\text { Various types of work performed to develop } \\
\text { wave energy device and other technologies } \\
\text { - People and factors that affect wave energy } \\
\text { device development and other technologies }\end{array}$ \\
\hline $\begin{array}{l}\text { Financing and } \\
\text { Revenues (34\%) }\end{array}$ & Money, power & $\begin{array}{l}\text { - Money issues related to innovation } \\
\text { development } \\
\text { - Acquiring money for innovation development } \\
\text { - Revenues from power generation }\end{array}$ \\
\hline $\begin{array}{l}\text { Government funding } \\
(21 \%)\end{array}$ & Funding, support & $\begin{array}{l}\text { Various funding sources obtained from } \\
\text { government to provide support to the different } \\
\text { project } \\
\text { Availability of funds is necessary for project } \\
\text { commencement }\end{array}$ \\
\hline $\begin{array}{l}\text { Company and } \\
\text { Business Network } \\
(27 \%)\end{array}$ & Company & $\begin{array}{l}\text { - Companies involved in early stage of the } \\
\text { commercialization effort } \\
\text { - Company as a listed company } \\
\text { - People in the company } \\
\text { - Involvement in other technologies, including } \\
\text { the wave energy device } \\
\text { - Suppliers/Partners/Investors that deal with the } \\
\text { company }\end{array}$ \\
\hline $\begin{array}{l}\text { Role of government } \\
(8 \%)\end{array}$ & Government & $\begin{array}{l}\text { - Government as a background influence - } \\
\text { government provides funding, support/non- } \\
\text { support for renewable energy } \\
\text { - Getting funds from government - money } \\
\text { received from government, importance of } \\
\text { funds to projects, and conditions of getting } \\
\text { funds } \\
\text { - Working with government - challenges and } \\
\text { attempts to influence/lobby government }\end{array}$ \\
\hline $\begin{array}{l}\text { Ownership and } \\
\text { control } \\
(8 \%)\end{array}$ & Board & $\begin{array}{l}\text { - Various people who join the board } \\
\text { - Decision made by the board of the different } \\
\text { companies involved in the commercialization } \\
\text { process }\end{array}$ \\
\hline
\end{tabular}

Note: In boldface the most frequently used concept within the theme. 
A number of important findings are obtained from Leximancer analysis (themes and concepts emphasized in italics). They are incorporated within the event analysis later in the paper:

- The company focused on the commercialization of the wave energy device and other technologies, which they believed to have potential. Eventually, it focused solely on the design of the wave energy device. The efforts were not just on a single device, but rather on a number of versions of the device (see footnote page 7).

- Commercialization effort was aimed at the power energy market, controlled in Western Australia by government. Moreover, business development must consider resources from both sales and grant funds (funding support). Government is simultaneously a customer (energy market), the provider of grant monies, and the owner of potential sites for devices. Thus, the relationship with government is multifaceted and complex.

- Acquiring money to support the technology and projects was an important part of commercialization. This finding is not new and reinforces other research on the importance of mobilizing financial resources during innovation development. In this case, government grant funds were critical to project development and if they were not available, the company would not pursue opportunities within those countries.

- Technology and project development were closely related (Figure 1, bottom right). Each project needed design and devices adapted around the natural environment for project installation. Because of this, it was difficult to separate the device innovation from project installation. Therefore, the context of the natural environment is influential on the path development of the innovation. Consequently, technical and commercialization paths are interrelated, and an ambidextrous path concept is developed for this case. More detail is provided in the discussion section.

- Commercialization involved many different companies - not just the effort of a sole company. This finding highlights the importance of the large variety of organizations (people) involved in the innovation's development, including: suppliers who worked selectively with the company to develop components, knowing there will be limited short-term return; government, as both a critical funding source (grants) and a customer (natural environment sovereign issues); local communities in which installation occurred or will be implemented; and competitors within the electrical generation market, including non-renewable and renewable technology providers. Therefore, relationships are crucial. 
- Government support influenced the commercialization path. This finding highlights that government influences how innovation develops, through being both customer and grant fund provider. Therefore, interaction with government (both domestic and international) is an important component in managing innovation paths in this industry.

\subsection{Event and Innovation Path Analysis and Results}

Drawing on Halinen et al. (2013) and Van de Ven et al. (2008), event and innovation path analysis involved four steps. For ease of presentation, the steps are presented sequentially; yet, this paper followed an abductive reasoning strategy, through iterative analysis of the four steps (Halinen \& Törnroos, 2005). In step 1 two researchers coded events and mapped them along a chronological timeline, which assisted in developing event driven explanations (Van de Ven \& Engleman, 2004). Events were coded into three categories: innovation activity processes, organizational changes, and actor interactions. Events were aggregated at the activity level to allow for the coding of resources used during each event and for sequencing the innovation paths. Event categories were developed from previous research including: Van de Ven et al. (2008), Håkansson \& Snehota (1995) and Chou \& Zolkewski (2012). This research differed from Van de Ven et al. (2008, e.g. chapter 5) who focused on coding via number of different events (e.g. bargaining, commitment and execution) and cumulating them over time. This research primarily examined resources used during each event and cumulated them across the innovation paths. Both researchers discussed the events as to their inclusion in the analysis and coded them according to the resources used during the activity. Resource coding involved a 'nil $=0$ ', 'low $=1$ ', 'medium $=2$ ' and 'high $=3$ ' category system (Purchase et al., 2014a) for all resource categories (financial capital, social capital, and both exploratory and exploitative knowledge). This step resulted in a relative assessment of resources used within each event. Results on event resources coding are provided in the Appendix 2. Table 3 and Figures 3 to 5 also display results of this step.

Step 2 involved coding events into 'lock-in', 'critical', 'related' and 'background' events (Halinen et al., 2013). 'Critical' events were coded if the following criteria were meet: (1) interviewees mentioned the event as important during their narration (Makkonen et al., 2012), (2) the event emerged in the concepts of the Leximancer analysis, and (3) the event radically changed the innovation development (following the definition proposed by Van de Ven et al., 2008, p. 73). For example, 'Funding awarded from government' is identified as a 'critical' 
event because: (1) the importance of government funding for the commencement and progress of projects was mentioned in the interviews: 'Whether [the specific project being discussed] comes to fruition... depends on how successful we are in getting some government grant funding.' (Managing Director and Board member); (2) funding has been identified as a significant theme in Leximancer result; and (3) the failure of acquiring funding has led the company to abandon some of its projects.

'Related' events have a direct influence on critical events, while 'background' events have an indirect influence on 'critical' events (Halinen et al., 2013). For instance, an event like 'Form Joint Venture' is identified as a related event, because it either directly leads to or results from a critical event of receiving funding for developing and testing a prototype. 'Background' events, for instance, 'New climate change initiative in Australia', are identified as events that shape the environment in which critical events occur.

Previously coded events identified as constraining future possible events were finally coded as 'lock-in' events along that particular path (e.g., in the second stage of the innovation, various grant funds, awarded by government, enabled the project to proceed using a particular technology, as indicated in Appendix 2. Although the same event may occur across multiple paths, the 'lock-in' effect may be unique to one path and not another. Table 3 summarizes the number of event categories for each of the six pathways and indicates the timing of 'lock-in' events (see also Appendix 4 for a graphical display of the event timing).

Table 3 Event Coding

\begin{tabular}{|l|r|r|r||l|l|}
\hline $\begin{array}{l}\text { Stage - Path / } \\
\text { Description of Path }\end{array}$ & $\begin{array}{l}\text { No. Critical } \\
\text { Events }\end{array}$ & $\begin{array}{l}\text { No. Related } \\
\text { Events }\end{array}$ & $\begin{array}{l}\text { No. } \\
\text { Background } \\
\text { Events }\end{array}$ & $\begin{array}{l}\text { Lock-in } \\
\text { Events }^{2}\end{array}$ & $\begin{array}{l}\text { Time for Lock-in } \\
\text { Events }\end{array}$ \\
\hline $\begin{array}{l}\text { 1-1 Obtaining full } \\
\text { ownership of } \\
\text { technology }\end{array}$ & 5 & 13 & 22 & $\begin{array}{l}2004 \text { (develop } \\
\text { and test } \\
\text { prototype) }\end{array}$ \\
\hline $\begin{array}{l}\text { 1-2 Initial technical } \\
\text { development }\end{array}$ & 5 & 14 & 12 & 1 & 2 \\
\hline $\begin{array}{l}\text { 1-3 Initial } \\
\text { commercialization }\end{array}$ & 13 & 14 & 12 & $\begin{array}{l}2004 \text { (list } \\
\text { company ASX) } \\
\text { 2007 (license SH) }\end{array}$ \\
\hline $\begin{array}{l}\text { 2-1 Continued } \\
\text { technical } \\
\text { development }\end{array}$ & 7 & 31 & 12 & 1 & $\begin{array}{l}2009 \text { (test version } \\
3)\end{array}$ \\
\hline
\end{tabular}

\footnotetext{
${ }^{2}$ These refer to total number of unique events with 'lock-in' characteristics at each stage.
} 


\begin{tabular}{|l|r|r|r||r||l|}
\hline $\begin{array}{l}\text { 2-2 Continued } \\
\text { commercialization }\end{array}$ & 9 & 30 & 15 & 1 & 2009 (acquire IP) \\
\hline $\begin{array}{l}\text { 2-3 Initial } \\
\text { commercial project }\end{array}$ & 6 & 16 & 11 & 4 & 2009 (funding A) \\
& & & & & 2012 (funding B) \\
& & & & & \\
& & & & & \\
\end{tabular}

Step 3 focused on the interdependencies between events and whether past events influence future events, similar to activity chains (Håkansson \& Snehota, 1995). This step was done with the advantage of hindsight, in that the researchers know the outcomes of events that were coded, while the actors would not have had this knowledge at the time. To undertake this step the researchers considered: whether the interviewee narrative indicated one event lead to another and if the documentary data indicated that one event was undertaken due to "outcome" or "result of" previous events (Figure 2). Investigating the interdependencies allowed the researchers to develop the innovation paths, which are sequences of events that are closely pooled together (Makkonen et al., 2012).

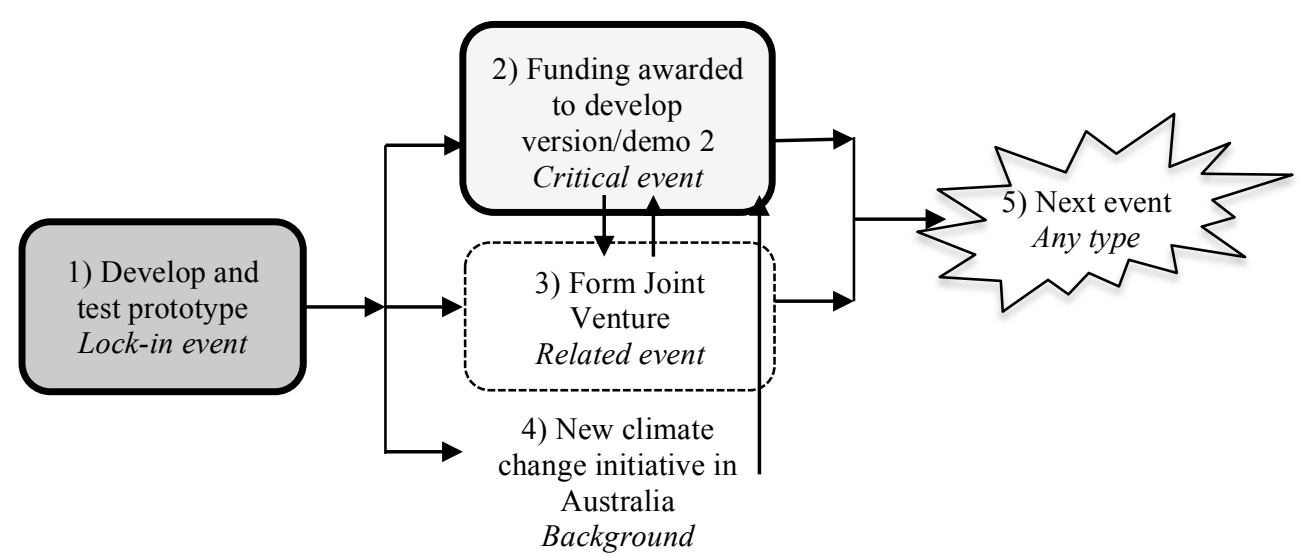

Figure 2: Example of sequence of events forming a path

Note: This diagram is an example only and events may follow in any order.

Once events were sequenced, innovation paths were developed, initially following Thrane et al. (2010). Yet, this step indicated that another path type, not aligned with Thrane et al. (2010), emerged: this path was termed ambidextrous innovation paths. This sequencing was essential when aggregating resources and profiling the paths.

Each path was also investigated on overall use of resources. Unlike technical or commercialization paths, ambidextrous paths seemed to have more even amounts of knowledge, social capital and financial capital, rather than one particular resource category prevailing in the mix (shown in Table 4). 
Table 4 Summary of Resource Use in Innovation Paths

\begin{tabular}{|l|l|l|l|l|l|}
\hline Stage - Path & Lock-in Event(s) & Path Category & $\begin{array}{l}\text { Knowledge } \\
\text { Resources }\end{array}$ & $\begin{array}{l}\text { Financial } \\
\text { Resources }\end{array}$ & $\begin{array}{l}\text { Social } \\
\text { Capital }\end{array}$ \\
\hline $\begin{array}{l}\text { 1-1 Obtaining full } \\
\text { ownership of } \\
\text { technology }\end{array}$ & $\begin{array}{l}\text { Develop and test } \\
\text { prototype }\end{array}$ & Ambidextrous & 24 & 25 & 25 \\
\hline $\begin{array}{l}\text { 1-2 Initial technical } \\
\text { development }\end{array}$ & $\begin{array}{l}\text { Develop and test } \\
\text { prototype }\end{array}$ & Technical & $\mathbf{3 9}$ & 25 & 24 \\
\hline $\begin{array}{l}\text { 1-3 Initial } \\
\text { commercialization }\end{array}$ & $\begin{array}{l}\text { Secure SH license } \\
\text { \& AIM }{ }^{3} \text { 2-listed } \\
\text { company formed to } \\
\text { commercialize } \\
\text { innovation }\end{array}$ & Commercialization & 19 & $\mathbf{3 7}$ & $\mathbf{4 9}$ \\
\hline $\begin{array}{l}\text { 2-1 Continued } \\
\text { technical } \\
\text { development }\end{array}$ & $\begin{array}{l}\text { Achieve milestones } \\
\text { for version 3 test }\end{array}$ & Ambidextrous & 48 & 42 & 64 \\
\hline $\begin{array}{l}\text { 2-2 Continued } \\
\text { commercialization }\end{array}$ & $\begin{array}{l}\text { Acquire 100\% of } \\
\text { IP }\end{array}$ & $\begin{array}{l}\text { Commercialization } \\
\text { 4-3 Initial } \\
\text { commercial project } \\
\text { the total of \$29 } \\
\text { million AUD }\end{array}$ & 25 & $\mathbf{4 1}$ & $\mathbf{6 4}$ \\
\hline
\end{tabular}

Note: Exploratory and exploitative knowledge were combined together. In boldface we highlight the dominating resources.

Figure 3, summarizes the results separately for the technical and two ambidextrous paths, then Figure 4 presents the three commercialization paths.

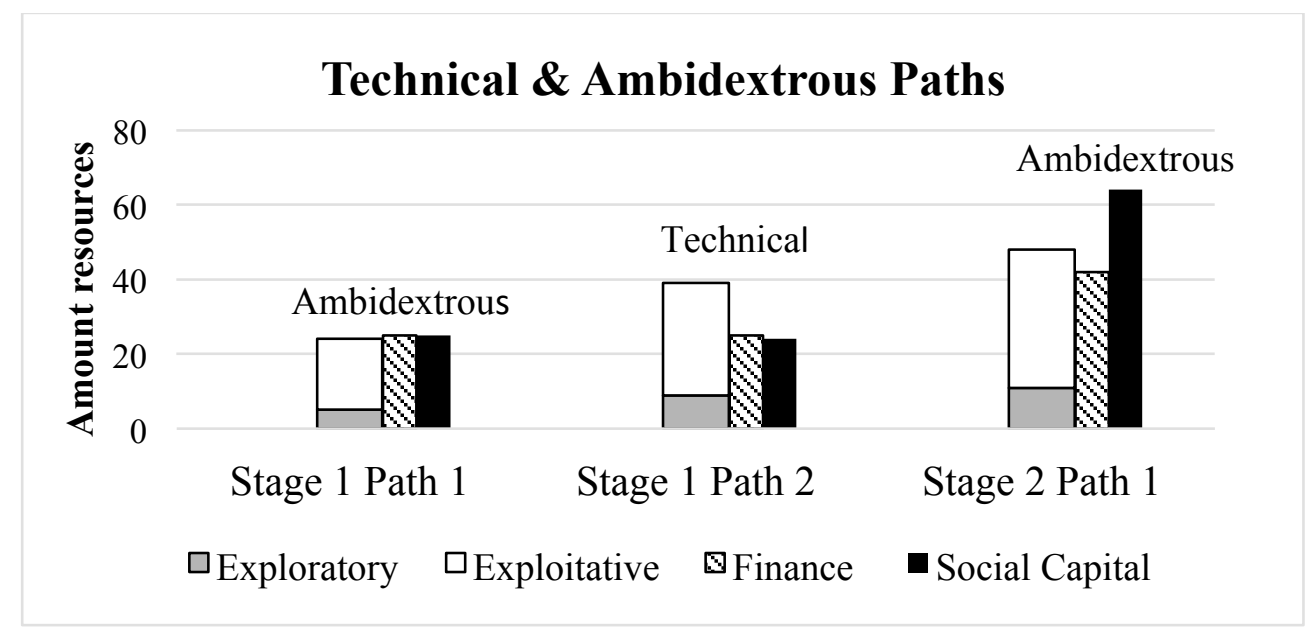

Figure 3: Resource Use for Technical and Ambidextrous Paths

\footnotetext{
${ }^{3}$ London Stock Exchange.
} 


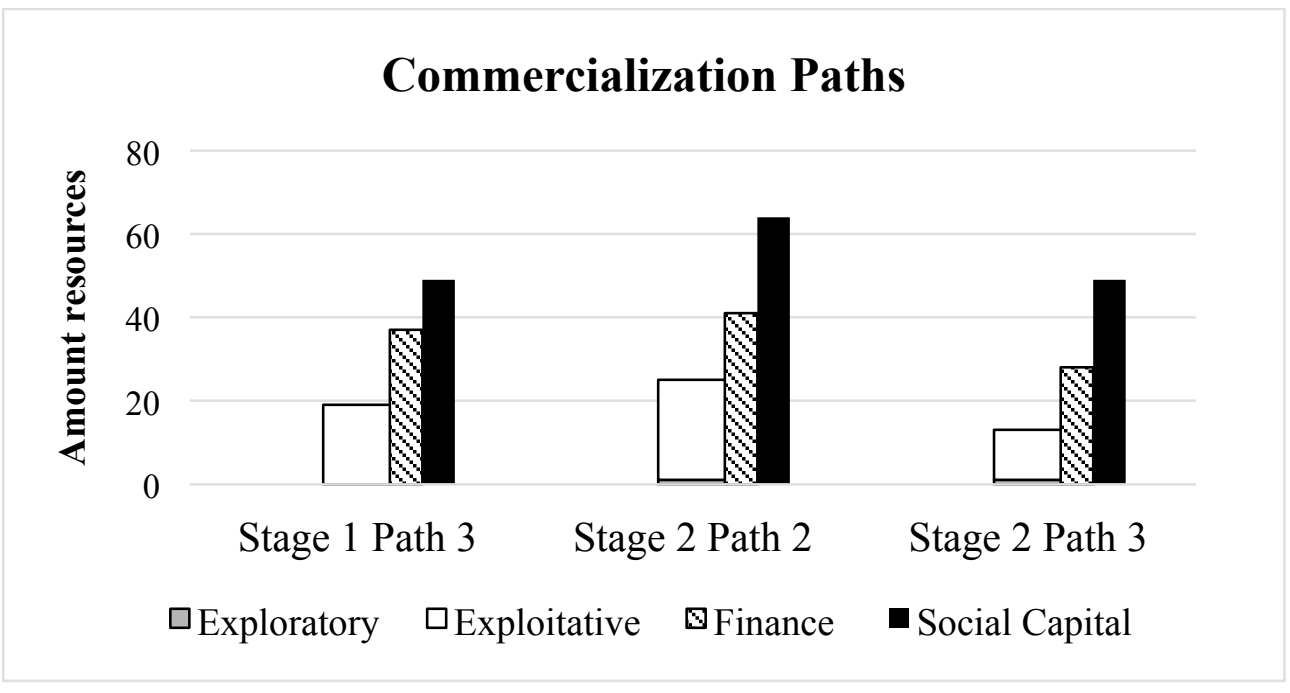

Figure 4: Resource Use for Commercialization Paths

The higher number of commercialization paths highlights the importance of commercialization along an innovation trajectory. Figures 3 and 4 also show that within the technical path (1-2), exploitative and exploratory knowledge resources are dominant (compared to total resources), whereas exploratory knowledge is not used to a great extent along the commercialization paths.

To compare resources used across different paths non-parametric $\chi^{2}$ tests were conducted. Significant associations were found between the type of path and knowledge resources $(p=0.0087)$ indicating that technical paths had a higher use of knowledge resources, compared to both ambidextrous and commercialization. Social capital $(p=0.0026)$ was used to a significantly greater extent across commercialization paths, compared to technical and to a lesser extent ambidextrous paths. Although financial resources were not significantly distinct across all three paths, pairwise comparisons showed they differed between technical and ambidextrous paths. These results reinforce the development of the ambidextrous path as different from both the technical and commercialization paths previously proposed by Thrane et al. (2010).

Step 4 involved cross path analysis, where the researchers investigated common events occurring across different paths and the sequencing and or convergence of paths across time. The findings, indicated in Table 5, emphasize the influence of common events across the different paths and how this effect shapes future possible paths that may emerge. Path numbering (from Tables 3 and 4) and event coding indicate commonality of events across the 
different paths. Common events occurring across all three paths in each stage were treated separately from events occurring across two paths only.

Table 5 Common Events

\begin{tabular}{|c|c|c|c|c|c|}
\hline \multirow[t]{2}{*}{ Stage } & \multirow{2}{*}{$\begin{array}{l}\text { Common } \\
\text { Paths }\end{array}$} & \multicolumn{3}{|c|}{ Frequency of Common Events } & \multirow{2}{*}{$\begin{array}{l}\text { Total } \\
\text { Events }\end{array}$} \\
\hline & & $\begin{array}{l}\text { All } \\
\text { Critical }\end{array}$ & $\begin{array}{l}\text { Critical \& } \\
\text { related }\end{array}$ & All related & \\
\hline \multirow{4}{*}{$\begin{array}{l}\text { Stage } \\
1\end{array}$} & $1-1,1-2,1-3$ & & 5 & & 5 \\
\hline & $1-1,1-2$ & & 1 & 2 & 3 \\
\hline & $1-1,1-3$ & & 4 & 2 & 6 \\
\hline & $1-2,1-3$ & & 4 & & 4 \\
\hline \multirow{4}{*}{$\begin{array}{l}\text { Stage } \\
2\end{array}$} & $2-1,2-2,2-3$ & & 3 & 1 & 4 \\
\hline & $2-1,2-2$ & & 3 & 8 & 11 \\
\hline & $2-1,2-3$ & 1 & 5 & 1 & 7 \\
\hline & $2-2,2-3$ & & & 2 & 2 \\
\hline
\end{tabular}

The tally suggests that although there are more common events in Stage 2 (24) than in Stage 1 (18), the number of common events that were coded critical (bold) were much higher for Stage 1 (e.g. 14) than for Stage 2 (e.g. 12). These findings indicate that before the decision to acquire $100 \%$ of intellectual property was made, there were a number of critical events occurring across multiple paths, $78 \%$ converging towards this important decision, whereas in stage 2 the convergence is yet to be achieved (only $50 \%$ of the common events were critical).

\section{Discussion}

\subsection{Academic Implications}

The results suggest three academic contributions when addressing the three research questions.

The first contribution refers to identifying a new innovation path type, expanding the previous taxonomies using innovation and technical paths (Thrane et al., 2010) or commercialization and technical paths (Purchase et al., 2014b). This case revealed another innovation path type, ambidextrous, described as an innovation path that simultaneously integrates diverse resources within innovation processes. Ambidextrous paths combined/integrated equal amounts of resources and they "balanced out" money, information, and 
interactions/relationships within the network. Unlike commercialization paths, which rely on financial resources and social capital, knowledge resources have a prime role in technical paths. The use of diverse resources requires diverse skill sets and capabilities, and is often aligned with a "middle" path between technical and commercialization. Our work broadens the definition of innovation ambidexterity put forward in the past as the use of exploratory and exploitative knowledge (e.g. Lin et al., 2013; Simsek et al., 2009) to embedding use of all resource categories, equally. Using diverse resources allows flexibility to adjust resource deployment quickly along the path, as these skills and capabilities are currently available within the network. Ambidextrous innovation paths significantly differ from technical and commercialization paths in their knowledge resources and social capital, and they seem to "lead" in both life stages of the innovation, which emphasises the criticality of their timing.

The second contribution is the role of resource use across the different paths and the timing of 'lock-in' events. 'Lock-in' events for technical and ambidextrous paths involve the reconfiguration of knowledge, while commercialization paths re-configure financial and social capital resources. Waluszewski and Håkansson (2007) indicate that re-configuring knowledge and network structure have path dependent characteristics influencing value creation. Our results indicate that knowledge use has path dependent characteristics through 'lock-in' events along technical and ambidextrous innovation paths. But 'lock-in' events along commercialization innovation paths are aligned to social capital resources, in other words who you know and interact with - aligning with network structure. Thus, our results build on Thrane et al. (2010) and Purchase et al. (2014b), indicating that different innovation path types have different resource deployment within their 'lock-in' events. In this case knowledge resources are used during the earlier innovation paths, while financial resources and social capital tend to 'lock-in' during the later innovation paths.

This research also highlights that 'lock-in' events for technical and ambidextrous paths occurred prior (chronologically earlier) than the 'lock-in' events along commercialization paths (Table 3). The timing of 'lock-in' events for stage 1 also shaped the ambidextrous path in stage 2 , therefore events and their sequencing should receive more attention in analysis of case studies in innovation (e.g. Woodside \& Biemans, 2005).

The last contribution refers to how common events (particularly 'critical' events) reinforce parallel paths, which lead to path convergence. Stage 1 has a much higher proportion of 
critical events (78\%) that are common events (Table 5), as the organization converges towards the first working prototype. Stage 2 displays a much lower force towards convergence with a lack of focus, particularly on using commercialization resources. This is also highlighted in the lower proportion of critical common events (50\%). The lack of focus resulted in many different market and funding opportunities being pursued with limited success. Thus, although the total amount of resources (Table 4) used towards events appears higher in Stage 2, the events did not reinforce each other, with the momentum of innovation success being less effective to date.

\subsection{Managerial Implications}

This research indicates that the resources used in 'lock-in' events change across the organization's life. For example when organizations begin, knowledge may 'lock-in' innovation paths, while later it is with whom the organization connects (network structure). This is demonstrated in the way the 'lock-in' events for technical and ambidextrous paths precedes those for commercialization. However, though knowledge will often be mobilized from their business network, managers need to consider a wide variety of relationships, so they do not restrict future paths. Yet, the knowledge the manager gains has a strong influence on future innovation paths. Once the innovation becomes more focused (i.e. knowledge 'lockin'), in this case concentrating on a particular IP, then relationship development needs to be more strategic. It is in these stages that network structure, or 'who you know', may generate 'lock-in' characteristics, possibly limiting future business models and/or customer development.

In terms of resource combination, the results also indicate that ambidextrous paths are present in both life stages of the innovation and lead the development in each stage. Although it is uncertain if this is a natural or optimal way to gear towards achieving desired performance, we argue that the timing of its events (a few years in advance of commercialization) create the premise for alignment and adaptability of the company. Further examination is needed to judge its applicability beyond the case and the industry, yet this finding may assist managers to plan in the long run, considering the level of mix of resources as a diagnostic tool for the company's development phase. Whereas on technical paths, exploitative and exploratory knowledge resources are dominant, on commercialization paths financial resources and social capital represent the main resources. As already indicated, the ambidexterity evens out the 
imbalances and leads the way. Still, achieving ambidexterity is associated with challenges (Gibson \& Birkinshaw, 2004).

Although this research split the innovation into two stages (around gaining control of IP), managers are unlikely to have a strict time point at which they will be able to change from knowledge acquisition to social capital development 'lock-in'. Therefore, as suggested, managers will need some flexibility in resource deployment, thus promoting some ambidextrous innovation paths early on. Further, commercialization paths display more 'lockin' events, which may be indicative of some convergence of the innovation paths. Acknowledging the uniqueness of each case, managers may consider using diverse resources to allow flexibility/adaptability to be achieved, however, when specialization of resources is emerging, the focus could switch to the 'lock-in' events.

Governments play important multifaceted roles making the network relationships more complex, thus becoming strategic relationships. For the renewable energy industry, government is often the financier (grant funding), customer (electrical power producer), competitor (electricity generator), and site owner (sovereignty of the natural environment). Accordingly, business relationships between the focal company and various government authorities occur along different innovation paths (e.g., technical, ambidextrous and commercialization). Given the different resource deployment across each of the innovation paths, renewable energy companies will need to develop capabilities in deploying and mobilizing diverse resources from a powerful network actor (government).

\section{Conclusion}

This research investigated innovation paths, types of events, and resource use for a wave energy development company within the renewable energy sector. An important contribution is the development of an ambidextrous innovation path where three separate, but interdependent and non-substitutable types of resources (knowledge, finance and social capital) are equally used; this being distinct from the technical and commercialization paths where one resource category is dominating. This research also highlights the importance of 'lock-in' events and their timing, in this case dominating the commercialization paths and occurring earlier in the technical and ambidextrous pathways. 
Future research should consider 'lock-in' events along innovation paths in more detail. Particularly, investigation of the time dependence in various settings would validate the findings and facilitate their applicability across a number of innovation types, industries, and even operation of business units. The development of innovation paths is also relatively recent and future research should consider further the impact of common events and consider the criticality of ambidextrous innovation paths in greater detail. Further research is needed to investigate whether the ambidextrous path category develops in other contexts/environments where spin-off innovations may occur.

Transition between paths is an under-developed area and how and when to do it is still not clear. There is evidence that ambidexterity comes at a cost and that it does not guarantee success by itself (O'Reilly \& Tushman, 2013). But we know far less about the "optimal" timing of ambidexterity and its long-term effect, especially where government has a complex role. Hence, the timing of events should receive more attention in the analysis of case studies in innovation, given their effects and an increasingly more dynamic business environment.

This research offers a number of insights in the mechanisms underlying the development of innovations, yet there are several limitations of these findings: this innovation within the renewable energy sector is unique, which requires further adaptation and research for every implementation scenario; because this is a single case study, future research should be undertaken across more cases and in other industries; the current temporal analysis is limited to associations between types of events, paths and resources, without an in-depth quantitative analysis of effects, resources, and conditions. 


\subsection{References}

Ambos, T., Mäkelä, K., Birkinshaw, J. \& D'Este, P. (2008). When Does University Research Get Commercialized? Creating Ambidexterity in Research Institutions. Journal of Management, 45(8), 1424-1447.

Araujo, L., \& Harrison, D. (2002). Path Dependence, Agency and Technological Evolution. Technology Analysis \& Strategic Management, 14(1), 5-19.

Arthur, B. (2009). The Nature of Technology. What It Is and How it Evolves. New York: Free Press.

Bairstow, N., \& Young, L. (2012). How channels evolve: A historical explanation. Industrial Marketing Management, 41(3), 385-393.

Babarit, A., Hals, J., Muliawan, M.J., Kurniawan, A., Moan, T., \& Krokstad, J. (2012). Numerical benchmarking study of a selection of wave energy converters. Renewable Energy, 41, 44-63.

Baraldi, E., \& Waluszewski, A. (2007). Conscious use of others' interface knowledge: how IKEA can keep the price of the Lack table constant over decades. In Håkansson, H. \& A. Waluszewski (Eds.), Knowledge and Innovation in Business and Industry: The importance of others (pp.79-108). New York: Routledge.

Chou, H.-H., \& Zolkiewski, J. (2012). Decoding Network Dynamics. Industrial Marketing Management, 41, 247-258.

Codini, A. (2015). Business networks along innovation life cycle. Journal of Business \& Industrial Marketing, 30(3/4), 329-341.

Creswell, J.W., \& Plano Clark, V.L. (2011). Designing and conducting mixed methods research $\left(2^{\text {nd }}\right.$ ed.) Thousand Oaks. CA: Sage.

Dagnino, G.B., Levanti, G., Minà, A., \& Picone, P.M. (2015). Interorganizational network and innovation: a bibliometric study and proposed research agenda. The Journal of Business \& Industrial Marketing, 30(3/4), 354-377.

Dosi, G. (1982). Technological paradigms and technological trajectories. Research Policy, 11, $147-162$.

Fadaeenejad, M., Shamsipour, R., Rokni, S.D., \& Gomes, C. (2014). New approaches in harnessing wave energy: With special attention to small islands. Renewable and Sustainable Energy Reviews, 29, 345-354.

Garud, R., \& Karnøe, P. (2013). Path Dependence and Creation. Taylor and Francis: United States.

Garud, R., Gehmanb, J., \& Giuliani, A.P. (2014). Contextualizing entrepreneurial innovation: A narrative perspective. Research Policy, 43(7), 1177-1188. 
Gibson, C.B., \& Birkinshaw, J. (2004). The antecedents, consequences, and mediating role of organizational ambidexterity. Academy of Management Journal, 47(2), 209-226.

Gupta, A.K., \& Govindarajan, V. (1991). Knowledge Flows and the Structure of Control within Multinational Corporations. The Academy of Management Review, 13(4), 768-792.

Håkansson, H., \& Snehota, I. (1995). Developing relationships in business networks. London: Routledge.

Halinen, A., \& Törnroos, J. (2005). Using case methods in the study of contemporary business networks. Journal of Business Research, 58(9), 1285-1297.

Halinen, A., Törnroos, J.-A., \& Elo, M. (2013). Network process analysis: An event based approach to study business network dynamics. Industrial Marketing Management, 42(8), $1213-1222$.

Hedaa, L., \& Törnroos, J.-A. (2008). Understanding Event-based Business Networks. Time \& Society, 17(2/3), 319-348.

Jenkins, M., \& Floyd, S. (2001). Trajectories in the Evolution of Technology: A Multi-level Study of Competition in Formula 1 Racing. Organization Studies, 22(6), 945-969.

Land, S., Engelen, A., \& Brettel, M. (2012). Top management's social capital and learning in new product development and its interaction with external uncertainties. Industrial Marketing Management, 41, 521-530.

Leech, N.L., \& Onwuegbuzie, A.J. (2009). A typology of mixed methods research designs. Quality and Quantity, 43(2), 265-275.

Leximancer Manual (2011), Leximancer Manual: version 4, accessed at [www.leximancer.com].

Lichtenstein, B., \& Brush, C. (2001). How do 'resource bundles' develop and change in new ventures? A dynamic model and longitudinal exploration. Entrepreneurship Theory and Practice, 25(3), 37-58.

Lin, H.-E., McDonnough, E., Lin, S.-J., \& Lin, C.Y.-Y. (2013). Managing the Exploitation/ Exploration Paradox: The Role of a Learning Capability and Innovation Ambidexterity. Journal of Product Innovation Management, 30(2), 262-278.

Makkonen, H., Aarikka-Stenroos, L., \& Olkkonen, R. (2012). Narrative approach in business network process research - Implications for theory and methodology. Industrial Marketing Management, 41(2), 287-299.

McCormick, M.E. (2013). Ocean Wave Energy Conversion. USA: Dover.

Munksgaard, K.B., \& Medlin, C. (2014). Self-and collective-interests: Using formal network activities for developing firms' business'. Industrial Marketing Management, 43(4), 613-621. 
Öberg, C., \& Shih, T.T. (2014). Divergent and convergent logic of firms: Barriers and enablers for development and commercialization of innovations. Industrial Marketing Management, 43(3), 419-428.

O'Reilly, C.A., \& Tushman, M.L. (2013). Organizational ambidexterity: Past, present, and future. Academy of Management Perspectives, 27(4), 324-338.

Raisch, S., \& Birkinshaw, J. (2008). Organizational ambidexterity: Antecedents, outcomes, and moderators. Journal of Management, 34(3), 375-409.

Ostendorf, J., Mouzas, S., \& Chakrabarti, R. (2014). Innovation in business networks: The role of leveraging resources. Industrial Marketing Management, 43(3), 504-511.

Partanen, J., Möller, K., Westerlund, M., Rajala, R. \& Rajala, A. (2008). Social capital in the growth of science-and-technology SMEs. Industrial Marketing Management, 37(5), 513-522.

Penn-Edwards, S. (2010). Computer Aided Phenomenography: The Role of Leximancer Computer Software in Phenomenographic Investigation. The Qualitative Report, 15(2), 252267.

Pérez-Luño, A., Cabello Medina, C., Carmona Lavado, A. \& Cuevas Rodríguez, G. (2011). How social capital and knowledge affect innovation. Industrial Marketing Management, 64(12), 1369-1376.

Purchase, S., Da Silva Rosa, R., \& Schepis, D. (2015). Identity construction through role and network processes. Industrial Marketing Management, Article in Press, http://dx.doi.org/10.1016/j.indmarman.2015.07.004.

Purchase, S., Olaru, D., \& Denize, S. (2014a). Innovation network trajectories and changes in resource bundles. Industrial Marketing Management, 43(3), 448-459.

Purchase, S., Kum, C., \& Olaru, D. (2014b). Resource mobilisation along technical and innovation trajectories. Proceedings of the $6^{\text {th }}$ meeting of IMP Group in Asia, Bali.

Rusanen, H., Halinen-Kaila, A., \& Jaakkola, E. (2014). Accessing resources for service innovation - the critical role of network relationships. Journal of Service Management, 25(1), 2-29.

Simmie, J., Sternberg, R., \& Carpenter, J. (2014). New technological path creation: evidence from the British and German wind energy industries. Journal of Evolutionary Economics, 24(4), 875-904.

Simsek, Z., Heavey, C., Veiga, J., \& Souder, D. (2009). A Typology for Aligning Organizational Ambidexterity's Conceptualizations, Antecedents, and Outcomes. Journal of Management Studies, 46(5), 864-894.

Smith, A., \& Humphreys, M. (2006). Evaluation of unsupervised semantic mapping of natural language with Leximancer concept mapping. Behaviour Research Methods, 38(2), 262-279. 
Sullivan, D. \& Marvel, M. (2011). Knowledge Acquisition, Network Reliance, and EarlyStage Technology Venture Outcomes. Journal of Management Studies, 48(6), 1169-1193.

Ståhl, B., \& Waluszewski, A. (2007). Use of knowledge in the model world: lesson to learn from economic literature. In Håkansson, H. \& A.Waluszewski (Eds) Knowledge and Innovation in Business and Industry: The importance of others (pp. 127-146). New York: Routledge.

Thrane, S., Blaabjerg, S., \& Møller, R. (2010). Innovative path dependence: Making sense of product and service innovation in path dependent innovation processes. Research Policy, 39, 932-944.

Tidström, A., \& Hagberg-Andersson, Å. (2012). Critical events in time and space when cooperation turns into competition in business relationships. Industrial Marketing Management, 41(2), 333-343.

Van de Ven, A., Polley, D., Garud, R., \& Venkataraman, S. (2008). The Innovation Journey. UK: Oxford University Press.

Van de Ven, A. \& Engleman, R. (2004). Event- and outcome-driven explanations of entrepreneurship, Journal of Business Venturing, 19(3), 343-358.

Villanueva, J., Van de Ven, A. \& Sapienza, H. (2012). Resource mobilization in entrepreneurial firms. Journal of Business Venturing, 27(1), 19-30.

Vohora, A., Wright, M., \& Lockett, A. (2004). Critical junctures in the development of university high-tech spinout companies. Research Policy, 33, 147-175.

Waluszewski, A., \& Håkansson, H. (2007). Economic use of knowledge. In Håkansson, H. \& A. Waluszewski (Eds) Knowledge and Innovation in Business and Industry: The importance of others (pp. 1-26). New York: Routledge.

Wolf, F. (2010). Enlightened eclecticism or hazardous hotschpotch? Mixed methods and triangulation strategies in comparative public policy research. Journal of Mixed Methods Research 4, 144.

Woodside, A., \& Biemans, W.G. (2005). Modeling innovation, manufacturing, diffusion and adoption/ rejection processes. Journal of Business \& Industrial Marketing, 20(7), 380-393.

Yli-Renko, H.K., Autio, E., \& Tontti, V. (2002). Social Capital, Knowledge Acquisition, and the International Growth of Technology-Based New Firms. International Business Review, $11,279-304$. 


\section{Appendix 1: Company Timeline}

1975: Inventor conceived the idea for wave energy device

2001: Company first began involved in wave energy device

2003: Company in consortium to develop wave energy device

Received first government grant and approval for in-sea testing

2004: Company in joint venture to develop wave energy device with UK listed partner

2005: Launch of first prototype

2007: Negotiated operating license for Southern Hemisphere

First attempt to raise fund for wave energy device from share market

UK listed partner formed partnership in France

Company seek opportunities in Australia

2008: UK listed partner formed partnership in Bermuda and applied for license to investigate its effectiveness in Canada

2009: Company acquired $100 \%$ IP for wave energy device

Received government grant and approval for first demo project in Australia

Received government grant and approval to investigate site in France

Received government grant to investigate potential sites in Canada

Received licenses for permission to investigate several sites in Australia

2010: Formed agreement with Ireland government agency to investigate possible sites in Ireland, UK

Received government grant to investigate possible sites in Ireland

Establish branch in Ireland, UK

Shelf a potential project in Australia due to failure at government funding

2011: Submitted and failed to received funding for a demo project in Canada (No further progress reported)

Formed partnership in Chile and completed site assessment (No further progress reported)

Selected site in Ireland and submitted application for project

2012: Deployment of wave energy device in France unsuccessful (Project stalled awaiting further funding)

Received further government funding to extend first demo project in Australia Released version five of the wave energy device

Completed initial wave study at Bermuda (No further progress reported)

UK Government publicized support for wave energy

2013: Received government grant for desalination project using wave energy device

Establish branch in UK

Raised capital for version 6 development

Received approval for project in Ireland (No further progress reported)

2014: Take up loan for version 6 development

Awarded project site in UK for version 6 demo

Received government grant for version 6 demo in Australia

First demo project close to completion

2015: Launch of first demo project (successful completion of first demo project)

Work on version 6 demo

Explore opportunities in UK and remote islands 
Appendix 2 Resources within Events

\begin{tabular}{|c|c|c|c|c|}
\hline Stage/Paths & $\begin{array}{l}\text { Exploratory } \\
\text { knowledge }\end{array}$ & $\begin{array}{l}\text { Exploitative } \\
\text { knowledge }\end{array}$ & \begin{tabular}{|l|} 
Financial \\
resources
\end{tabular} & $\begin{array}{l}\text { Social } \\
\text { Capital }\end{array}$ \\
\hline \multicolumn{5}{|c|}{ 1-1 Obtaining full ownership of technology - Ambidextrous } \\
\hline Inventor conceived various inventions & 3 & 0 & 0 & 0 \\
\hline First rename of the company & 0 & 0 & 1 & 0 \\
\hline Decide to expand beyond mining to technologies & 0 & 0 & 0 & 0 \\
\hline Investigate wave device & 0 & 1 & 1 & 0 \\
\hline Acquired $50 \%$ of the wave device & 0 & 2 & 1 & 3 \\
\hline Awarded $\$ 600,000$ grant & 0 & 0 & 1 & 1 \\
\hline Formed joint venture & 0 & 1 & 2 & 3 \\
\hline Develop \& test prototype & 2 & 3 & 2 & 3 \\
\hline AIM-listed company formed to commercialize wave device & 0 & 1 & 3 & 3 \\
\hline AIM-listed company acquired joint venture & 0 & 3 & 2 & 3 \\
\hline Recruit Manager of Innovation \& Technology & 0 & 1 & 1 & 0 \\
\hline Decide to focus on clean energy & 0 & 1 & 0 & 0 \\
\hline Separate mining activities & 0 & 0 & 2 & 0 \\
\hline Secure SH license & 0 & 3 & 3 & 2 \\
\hline Raised $\$ 5.75 \mathrm{~m}$ from SP & 0 & 0 & 2 & 1 \\
\hline Second rename of the company & 0 & 0 & 1 & 0 \\
\hline Acquire $100 \%$ IP & 0 & 3 & 3 & 3 \\
\hline Restructure of the company's board & 0 & 0 & 0 & 3 \\
\hline \multicolumn{5}{|l|}{ 1-2 Initial technical development - Technical } \\
\hline Inventor conceived various inventions & 3 & 0 & 0 & 0 \\
\hline Initial desktop design & 0 & 3 & 1 & 0 \\
\hline Investigate wave device & 0 & 1 & 1 & 0 \\
\hline Perform wave tank testing & 0 & 2 & 1 & 0 \\
\hline Acquired $50 \%$ of the wave device & 0 & 2 & 1 & 3 \\
\hline Formed joint venture & 0 & 1 & 2 & 3 \\
\hline Awarded $\$ 600,000$ grant & 0 & 0 & 1 & 1 \\
\hline Brainstorm on design & 1 & 3 & 0 & 3 \\
\hline Assemble team \& construct plan & 0 & 0 & 1 & 2 \\
\hline Develop \& test prototype & 2 & 3 & 2 & 3 \\
\hline AIM-listed company acquired joint venture & 0 & 3 & 2 & 3 \\
\hline Developed \& tested ver 2 & 1 & 3 & 2 & 1 \\
\hline Refine ver 2 design & 1 & 3 & 0 & 0 \\
\hline Raised $\$ 14.8 \mathrm{~m}$ for innovation \& tech & 0 & 0 & 2 & 1 \\
\hline Sold AIM-listed company shares & 0 & 0 & 2 & 0 \\
\hline Raised $\$ 1.18$ from SPP \& SP & 0 & 1 & 2 & 2 \\
\hline Prelim design for demo project in Australia & 0 & 2 & 0 & 0 \\
\hline Raised $\$ 5.75 \mathrm{~m}$ from SP & 0 & 0 & 2 & 1 \\
\hline Developed ver 3 design & 1 & 3 & 3 & 1 \\
\hline \multicolumn{5}{|l|}{ 1-3 Initial commercialization - Commercialization } \\
\hline Acquired $50 \%$ of the wave device & 0 & 2 & 1 & 3 \\
\hline Awarded $\$ 600,000$ grant & 0 & 0 & 1 & 2 \\
\hline Formed joint venture & 0 & 1 & 2 & 3 \\
\hline AIM-listed company formed to commercialize wave device & 0 & 1 & 3 & 3 \\
\hline AIM-listed company to acquire joint venture & 0 & 3 & 2 & 3 \\
\hline Secure SH license & 0 & 3 & 3 & 2 \\
\hline Raised $\$ 14.8 \mathrm{~m}$ for innovation \& technology & 0 & 0 & 2 & 1 \\
\hline Made proposal for demo in Australia & 0 & 2 & 1 & 0 \\
\hline Search for commercial opportunities & 0 & 0 & 0 & 0 \\
\hline Formed French partnership & 0 & 1 & 2 & 2 \\
\hline Sold AIM-listed company shares & 0 & 0 & 2 & 0 \\
\hline Raised $\$ 1.18 \mathrm{~m}$ from SPP \& SP & 0 & 1 & 2 & 2 \\
\hline Raised $\$ 2.5 \mathrm{~m}$ through PP & 0 & 0 & 2 & 2 \\
\hline
\end{tabular}




\begin{tabular}{|c|c|c|c|c|}
\hline Stage/Paths & $\begin{array}{l}\text { Exploratory } \\
\text { knowledge }\end{array}$ & $\begin{array}{l}\text { Exploitative } \\
\text { knowledge }\end{array}$ & $\begin{array}{l}\text { Financial } \\
\text { resources }\end{array}$ & $\begin{array}{l}\text { Social } \\
\text { Capital }\end{array}$ \\
\hline Formed Canadian subsidiary & 0 & 0 & 1 & 2 \\
\hline Awarded CAD $\$ 2 \mathrm{~m}$ Canadian project & 0 & 0 & 2 & 2 \\
\hline Formed Bermuda partnership & 0 & 0 & 1 & 1 \\
\hline Applied for Bermuda demo & 0 & 2 & 1 & 0 \\
\hline Presented at conferences $\&$ seminars & 0 & 0 & 1 & 2 \\
\hline Receive license to investigate various Australian sites & 0 & 0 & 0 & 2 \\
\hline Entered discussion for desalination project & 0 & 0 & 0 & 1 \\
\hline Raised $\$ 5.75 \mathrm{~m}$ from SP & 0 & 0 & 2 & 1 \\
\hline Acquire $100 \%$ IP & 0 & 3 & 3 & 3 \\
\hline Restructure of the company's board & 0 & 0 & 0 & 3 \\
\hline Second rename of the company & 0 & 0 & 1 & 0 \\
\hline Awarded $£ 3 \mathrm{~m}$ for French project & 0 & 0 & 2 & 3 \\
\hline Signed MoU to investigate offshore site & 0 & 0 & 0 & 3 \\
\hline Awarded $\$ 12.5 \mathrm{~m}$ grant & 0 & 0 & 0 & 3 \\
\hline \multicolumn{5}{|l|}{ 2-1 Continued technical development - Ambidextrous } \\
\hline Developed ver 3 & 1 & 3 & 3 & 1 \\
\hline Raised money & 0 & 0 & 3 & 3 \\
\hline Select offshore site for ver 3 test & 0 & 0 & 0 & 2 \\
\hline Awarded \$12.5m LEED grant & 0 & 0 & 0 & 3 \\
\hline Achieve milestone for ver 3 test & 0 & 3 & 0 & 2 \\
\hline Presented at conferences \& seminars & 0 & 2 & 1 & 1 \\
\hline Milestone payments from funding & 0 & 0 & 3 & 0 \\
\hline Collaborate on French project & 0 & 0 & 2 & 3 \\
\hline Developed ver 4 & 1 & 3 & 0 & 3 \\
\hline Developed ver 5 & 1 & 3 & 2 & 2 \\
\hline Deployment of ver 4 failed & 0 & 0 & 1 & 0 \\
\hline Awarded $\$ 9.9 \mathrm{~m}$ grant & 0 & 0 & 0 & 3 \\
\hline Awarded $\$ 5.5 \mathrm{~m}$ grant & 0 & 0 & 0 & 3 \\
\hline Select offshore site for commercial project & 0 & 0 & 3 & 2 \\
\hline Design \& construct commercial project & 0 & 3 & 3 & 3 \\
\hline Received \$2.26m R\&D tax refund & 0 & 0 & 2 & 0 \\
\hline Awarded $\$ 1.27 \mathrm{~m}$ for desalination & 0 & 0 & 0 & 3 \\
\hline Raised $\$ 4 \mathrm{~m}$ from convertible notes & 0 & 0 & 2 & 0 \\
\hline Partner to research device array & 1 & 3 & 2 & 3 \\
\hline Continue tech development & 0 & 0 & 0 & 0 \\
\hline Developed ver 6 & 1 & 3 & 0 & 2 \\
\hline Design \& construct desalination plant & 0 & 3 & 2 & 1 \\
\hline Secure $\$ 20 \mathrm{~m}$ CFC loan & 0 & 0 & 3 & 3 \\
\hline Select sites for ver 6 & 0 & 0 & 2 & 0 \\
\hline Awarded $\$ 11 \mathrm{~m}$ fund for offshore site & 0 & 0 & 0 & 3 \\
\hline Awarded UK site for ver 6 & 0 & 0 & 0 & 3 \\
\hline Awarded EU fund for ver 6 & 0 & 0 & 2 & 3 \\
\hline Collaborate on tidal \& wave research & 1 & 2 & 1 & 2 \\
\hline Partake in R\&D study & 1 & 2 & 2 & 2 \\
\hline Partner U. Adelaide for ver 6 research & 1 & 3 & 0 & 2 \\
\hline Collaborate to develop WavePOD & 2 & 2 & 1 & 3 \\
\hline New partner for environmental research & 1 & 2 & 2 & 3 \\
\hline \multicolumn{5}{|l|}{ 2-2 Continued commercialization - Commercialization } \\
\hline Acquire $100 \%$ IP & 0 & 3 & 3 & 3 \\
\hline Raised money & 0 & 0 & 3 & 3 \\
\hline Investigate Canadian site & 0 & 3 & 2 & 2 \\
\hline Re-formed agreement with French partner & 0 & 0 & 0 & 2 \\
\hline Bermuda demo selected & 0 & 0 & 0 & 1 \\
\hline Search for commercial opportunities & 0 & 0 & 0 & 0 \\
\hline Perform feasibility assessment at various site & 0 & 3 & 2 & 2 \\
\hline Presented at conferences \& seminars & 0 & 2 & 1 & 1 \\
\hline
\end{tabular}




\begin{tabular}{|c|c|c|c|c|}
\hline Stage/Paths & $\begin{array}{l}\text { Exploratory } \\
\text { knowledge }\end{array}$ & $\begin{array}{l}\text { Exploitative } \\
\text { knowledge }\end{array}$ & $\begin{array}{l}\text { Financial } \\
\text { resources }\end{array}$ & $\begin{array}{l}\text { Social } \\
\text { Capital }\end{array}$ \\
\hline Collaborate on French project & 0 & 0 & 2 & 3 \\
\hline Signed agreement to develop Irish project & 0 & 0 & 0 & 3 \\
\hline Formed Irish subsidiary & 0 & 0 & 1 & 2 \\
\hline Awarded $€ 74,000$ for Irish project & 0 & 0 & 2 & 3 \\
\hline Milestone payments from funding & 0 & 0 & 3 & 0 \\
\hline Developed ver 4 & 1 & 3 & 0 & 3 \\
\hline Failure to secure Canadian funding & 0 & 0 & 0 & 0 \\
\hline Establish Chilean subsidiary & 0 & 0 & 1 & 2 \\
\hline Determine \& investigate site in Ireland & 0 & 3 & 2 & 2 \\
\hline Hosted various visitors & 0 & 2 & 1 & 1 \\
\hline Deployment of ver 4 failed & 0 & 0 & 1 & 0 \\
\hline Awarded $\$ 9.9 \mathrm{~m}$ grant & 0 & 0 & 0 & 3 \\
\hline Awarded $\$ 5.5 \mathrm{~m}$ grant & 0 & 0 & 0 & 3 \\
\hline Secure $\$ 16.3 \mathrm{~m}$ funding & 0 & 0 & 3 & 2 \\
\hline Complete Bermuda site assessment & 0 & 3 & 2 & 2 \\
\hline Awarded $\$ 1.27 \mathrm{~m}$ grant & 0 & 0 & 0 & 3 \\
\hline Received $\$ 2.26 \mathrm{~m}$ R\&D tax refund & 0 & 0 & 2 & 0 \\
\hline Raised $\$ 4 \mathrm{~m}$ from convertible notes & 0 & 0 & 2 & 0 \\
\hline Formed UK subsidiary & 0 & 0 & 1 & 2 \\
\hline New partner for research & 0 & 2 & 0 & 2 \\
\hline Secure $\$ 20 \mathrm{~m}$ CFC loan & 0 & 0 & 3 & 3 \\
\hline Select sites for ver 6 & 0 & 0 & 2 & 0 \\
\hline Awarded EU fund for ver 6 & 0 & 0 & 0 & 3 \\
\hline Awarded UK site for ver 6 & 0 & 0 & 0 & 3 \\
\hline Awarded $\$ 11 \mathrm{~m}$ fund for offshore site & 0 & 0 & 0 & 3 \\
\hline Raised \$9m from SPP \& PP & 0 & 0 & 2 & 2 \\
\hline \multicolumn{5}{|l|}{ 2-3 Initial commercial project - Commercialization } \\
\hline Awarded $\$ 12.5 \mathrm{~m}$ LEED fund & 0 & 0 & 0 & 3 \\
\hline Select offshore site for ver 3 test & 0 & 0 & 0 & 2 \\
\hline Raised $\$ 8.86 \mathrm{~m}$ from SPP \& SP & 0 & 0 & 2 & 3 \\
\hline Search for commercial opportunities & 0 & 0 & 0 & 0 \\
\hline Achieve milestones for ver 3 test & 0 & 3 & 0 & 2 \\
\hline Signed MoU to investigate offshore site & 0 & 0 & 0 & 3 \\
\hline Milestone payments from funding & 0 & 0 & 3 & 0 \\
\hline Raised $\$ 6.2 \mathrm{~m}$ from SPP & 0 & 0 & 2 & 1 \\
\hline Develop ver 5 & 1 & 3 & 2 & 2 \\
\hline Raised $\$ 4 \mathrm{~m}$ from $\mathrm{SP}$ & 0 & 0 & 2 & 3 \\
\hline Raised $\$ 6 \mathrm{~m}$ from SPP & 0 & 0 & 2 & 1 \\
\hline Secure $\$ 16.3 \mathrm{~m}$ funding & 0 & 0 & 3 & 2 \\
\hline Awarded $\$ 9.9 \mathrm{~m}$ grant & 0 & 0 & 0 & 3 \\
\hline Awarded $\$ 5.5 \mathrm{~m}$ grant & 0 & 0 & 0 & 3 \\
\hline Raised $\$ 5.8 \mathrm{~m}$ from government \& private organizations & 0 & 0 & 2 & 3 \\
\hline Select offshore site for commercial project & 0 & 0 & 3 & 2 \\
\hline $\begin{array}{l}\text { Signed supply \& grid connection agreement for offshore } \\
\text { site }\end{array}$ & 0 & 0 & 0 & 3 \\
\hline Design \& construct commercial project & 0 & 3 & 3 & 3 \\
\hline Awarded $\$ 1.27 \mathrm{~m}$ for desalination & 0 & 0 & 0 & 3 \\
\hline Raised $\$ 9.5 \mathrm{~m}$ from SPP \& PP & 0 & 0 & 2 & 3 \\
\hline Formed support agreement for desalination & 0 & 0 & 0 & 3 \\
\hline Design \& construct desalination plant & 0 & 3 & 2 & 1 \\
\hline
\end{tabular}

Note: Italics indicate lock-in events. 


\section{Appendix 3 Glossary of Terms}

Social capital - features (such as trust, norms, and linkages), that characterize the structure of a network, facilitate exchange and cooperation, and improve network functionality; the sum of resources that a firm can access or mobilize by virtue of possessing a durable network of relationships' (YliRenko et al. 2002, p.282).

Financial capital - money, credit resources that can be used to acquire knowledge and develop social capital (Rusanen et al., 2014). Financial resources allow for a greater amount of experimentation, which leads to improved novelty and consequently higher long-term innovation performance.

Exploratory knowledge - described as knowledge aligned with technological experimentation, search for new ideas and possibilities.

Exploitative knowledge - knowledge aligned with technological extension and refinement (Land et al., 2012). It also includes choice, production/implementation, and execution efficiency.

Ambidexterity - 'an organization's ability to perform differing and often competing strategic acts at the same time' (Simsek et al. 2009, p. 865). Organizational ambidexterity requires balancing resources simultaneously. Ambidexterity is positively related to growth rate, improved performance, maintained stability (O’Reilly \& Tushman, 2013).

Events - 'temporally specific outcomes of performed acts by actors' (Hedaa \& Törnoos, 2008, p. 324) that require resources (Chou \& Zolkiewski, 2012).

Critical events - key actions/activities that drive the progression of the innovation or are points of departure from current process directions (Tidström \& Hagberg-Andersson, 2012).

Related events - actions or activities that directly trigger or result from critical events, but do not carry significance to the innovation process by themselves.

Background events - relate to the context in which the innovation is embedded, such as macroenvironmental context and institutional forces.

Lock-in events - events that constrain future events (Arthur, 2009).

Innovation paths - sequences of innovation events unfolding, where future events are serially dependent on the patterns of past events (Araujo \& Harrison, 2002; Makkonen et al., 2012).

Ambidextrous paths - innovation paths where all resources are combined/integrated in a balanced way. 
Appendix 4: Temporal Variation of the Number of Events by Stage
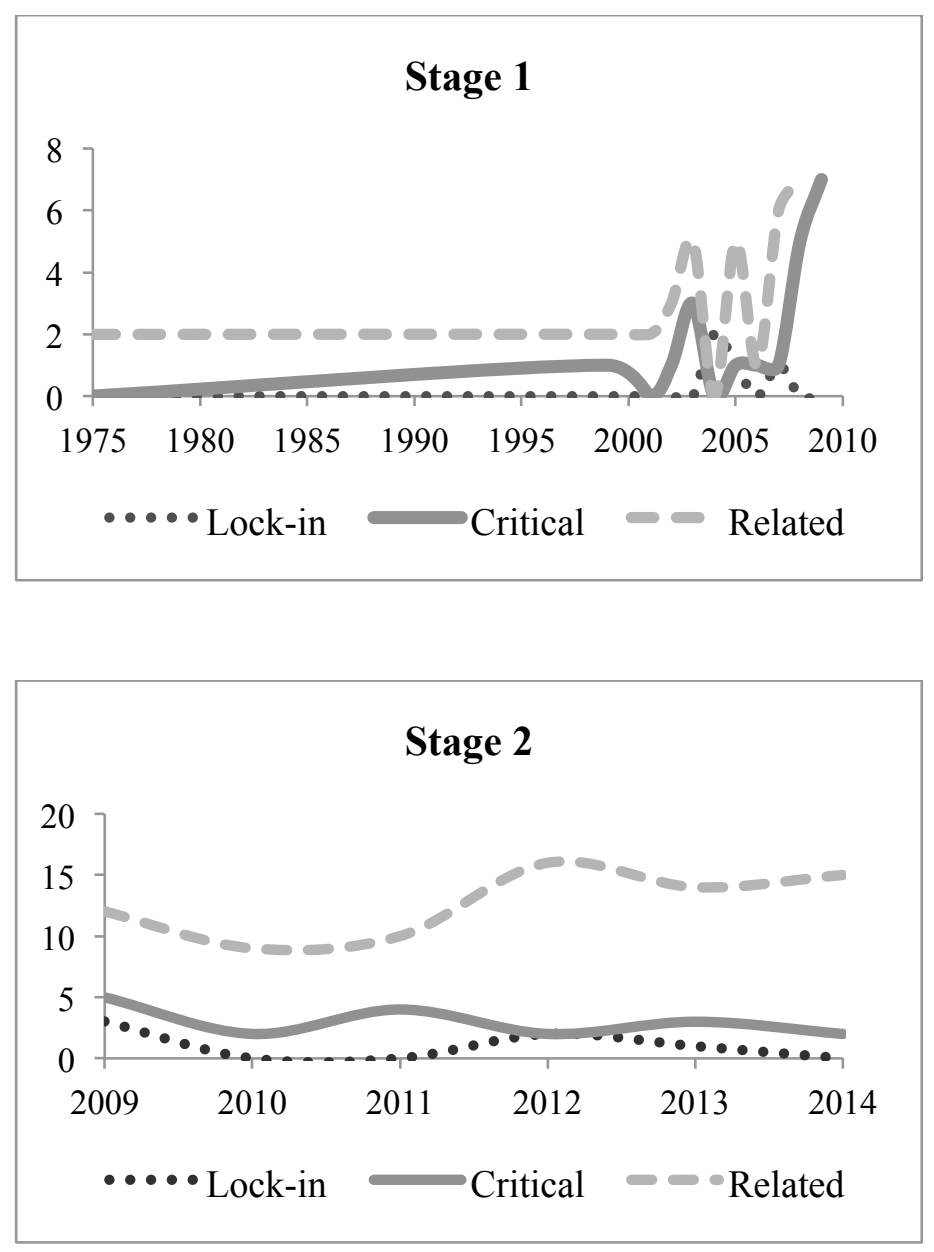